\title{
"Eating the Stones of the Earth": Romancing the Scientific Production of Food in Technological Utopias
}

\section{Teresa Botelho FCSH/UNL/CETAPS}

\begin{abstract}
In many examples of contemporary speculative fiction, the projection of possible futures, shaped by concerns over the preservation of the ecosystem and the integrity of species, uses the cultural tropes of food production and consumption as symbolic tools to represent loss or threat to what seems the order of the natural world. Conventional and natural food is often invested as an anchor of familiarity in imagined changed worlds, frequently functioning as a signifier of nostalgic resistance against the new social and cultural order, while new artificial foodstuffs perform the function of accentuating the pre-apocalyptic or post-apocalyptic collapse of the natural and the pastoral. This rejection of the intrusion of high technology in food production contrasts with the dream of sterile scientific food production detached from agricultural practices that emerges in several nineteenth- and early twentieth-century American utopias. This paper discusses two of these texts, Mizora, by Mary Bradley Lane (1898), the first literary imagining of a women-exclusive nonpatriarchal society, and Roadtown, by Edgar Chambless (1910), and examines how they project strategically opposite dreams of the relation between the agricultural and the laboratorial, the natural and the technological, as represented by the protocols of food production and consumption.
\end{abstract}

Keywords: Food, Sci-Fi, Utopia, technology

Resumo: Em muitos exemplos de ficção especulativa contemporânea, a projeção de futuros possíveis, moldada por preocupações com a preservação do ecossistema e a integridade das espécies, usa paradigmas culturais da produção e do consumo de alimentos como ferramentas simbólicas para representar a perda ou a 
ameaça ao que parece ser a ordem do mundo natural. 0 alimento natural e convencional é frequentemente utilizado como um símbolo de familiaridade em mundos imaginados, funcionando com frequência como significante da resistência nostálgica à nova ordem social e cultural, enquanto novos alimentos artificiais desempenham a função de acentuar o colapso pré ou pós-apocalíptico do natural e do pastoril. Este repúdio da intrusão da alta tecnologia na produção alimentar contrasta com o sonho da produção de alimentos científicos estéreis, longe das práticas agrícolas promovidas por várias utopias americanas do século XIX e início do século XX. O presente artigo discute dois desses textos - Mizora, de Mary Bradley Lane (1898), a primeira projeção literária de uma sociedade não patriarcal e exclusiva de mulheres, e Roadtown, de Edgar Chambless (1910) -, refletindo sobre a forma como eles projetam sonhos estrategicamente opostos da relação entre o agrícola e o laboratorial, o natural e o tecnológico, representada pelos protocolos de produção e consumo de alimentos.

Palavras-chave: alimentação, ficção científica, utopia, tecnologia

\section{Food in the mapping of speculative fictional worlds}

In the first pages of The Tomorrow File, a relatively obscure work by American author Lawrence Sanders written in 1975' , when little is known about the contours of the futuristic world invoked by the title, readers are apprised of much of its structure and texture by witnessing a meal. Two men are sitting at a table in the Executive Dining Room of a high-end restaurant in what used to be Manhattan, now part of Geopolitical Area 12. They are Nicholas Bennington Flair, the protagonist, an NM (natural male) who is a section director of the Department of Bliss (the new designation for what was once the Department of Health, Education and Welfare), and his assistant and regular sexual partner or "user" Paul Bumford, an AINM- $\mathrm{A}^{3}$ (artificially inseminated male with Grade A genetic ratings). Although their conversation is revealing of a social setting that clearly evokes Huxley's Brave New World ${ }^{4}$ - they are debating the pressures to change the Fertility Control Act to allow natural ems and efs (naturally born males and females) to procreate without licensing - what they are eating is perhaps more illuminating: on their plates are servings of prosteak, propots and probeans, the artificially created foodstuff that had become the new normal since the synthesizing of protein from petroleum had moved from the laboratory to 
the commercial domain. Looking at his dinner, Nicholas, old enough to have lived in the days before pro-food, suffers a mild attack of RSC, Random Synaptic Control, that brings back memories... of his father making a fortune in the new food industry, of his mother's refusal to consume any synthetic food or drink. Of course he carries memory suppressing pills, but before they take effect he is overcome by "atavistic memories of the taste of farmfresh eggs, vine-ripened melons, cucumbers, fresh beef, gravel-scratching chickens, wine made from grapes..." (16), an invasion of consciousness that he likens to Proust's, who could "write a novel of that length inspired by a madeleine soaked in tea" (15).

Readers of dystopian literature are likely to attach a specific significance to these signs, cued perhaps by the significance of other meals, namely of those occurring in Nineteen Eighty-Four, when Winston, eating the tasteless grub of the Ministry of Truth canteen, wonders if food "had always been like this" (1978:51) or when, sharing a small bar of real chocolate and some real coffee with Julia, he is taken over by vague emotional and troubling memories that he cannot quite put aside, but which, as Parasecoli argues, "are stronger than any propaganda," working as "a compass directing him to a past" that will ignite a new sense of selfhood (Parasecoli, 2008:67) fundamental to the character's growing disaffection.

This identification of a recognizable trope, prompted by the association of the replacement of natural food by industrial fare with a cluster of negative signifiers, may also be complemented by the expectation that Nicholas' untamable nostalgic sensitivity will make him a potential rebel against the system he serves. This comes even before readers know that he is addicted to real coffee, which he buys secretly from illegal coffee pushers, and that he keeps a forbidden stash of art books in his parents' house, which he visits twice a year to engage in the most obsolete and dangerous of pleasures-looking at reproductions of Matisse and slowly sipping his most treasured possession, a bottle of real Cognac that he acquired when they could still be found on the black market.

In contrast, fictional meals can be seen to perform the narrative function of familiarizing the unfamiliar. This is the case of a breakfast in the first pages of the stunningly heterotopic world of China Miéville's Perdido Street Station (2000), when Isaac, a 
man, and Lin, his Xenian ${ }^{5}$ lover, a Kephri ${ }^{6}$ artist who has the upper body of an insect and is human-like below her waist, are sharing breakfast. This is described as an awkward moment when her alienness seems most patent to Isaac, "as sharing meals was both a challenge and an affirmation" of the daring and power of their interspecies love (13). We are told that their table conversation is usually one-sided because, having no human mouth and vocal cords, Lin communicates by sign language, and she needs her hands and antennae to take food to her mandibles. But in this radically different world of Bas-Lag, in the radically unexpected city of New Corbuzon where everything surprises the reader, both Lin and Isaac share startling conventional food, namely eggs and fruit, root vegetables and fresh tomatoes that are sold below their window by a street vendor. This description gives the disconcerting impossibility of the world of the narrative the sudden light of actuality. This is, as Laurel Forster points out, the same kind of dynamic that shapes the famous scene in the film The Matrix, when Neo meets the Oracle in a conventional kitchen, where the absolute strangeness of what she has to say is somehow mitigated by the deliciousness of the cookies that she is baking, which, even if prepared within the unreality of the virtual world, represent "intangible qualities beyond the limits of the simulation, such as sincerity, compassion and farsightedness" (2004:263)

These and many other examples of meals in contemporary speculative fiction, especially of the dystopian and heterotopian kind, illuminate the role that food production and consumption frequently plays in narrative strategies of world building, as the materiality and indispensability of the body-sustaining act of eating turns its literary renditions into shorthand signifiers of a number of cultural divergences. Some of these are directly related to the distribution of power implied by access to food. Illuminating examples of these dynamics can be seen at play in Margaret Atwood's The Handmaid's Tale (1999), where the diet of the designated mothers-to-be is strictly controlled so that "they are permitted to consume only that which the authorities consider will enhance their health and fertility" (Parker, 1995:354), or in Paolo Bacigalupi's "agri-punk"7 novella The Calorie Man (2008) where large conglomerates like AgriGen that hold all botanical patents exert absolute power over the lives of a post-famine population. In other texts, like those already 
mentioned, it is the fundamental opposition between natural and artificial that is enacted, confirming Ritzenger's observation that food "not only signifies the needs of the individual biological body and the grammar of a particular society and culture", but also our fundamental connection with the environment "and simultaneously our indebtedness to science and technology" (2008:371).

This intimate and cultural network of implications explains the attention given to the preparation and consumption of food in speculative fiction, either as a mechanism of cognitive estrangement, frequently representing the planned or accidental collapse of the natural, or as a sign of an authoritarian exercise of power in the name of technological progress, or as an anchor of familiarity in imagined alternative worlds.

This role of food as one of the most fundamental connections with the environment, a "liminal substance", as Atkinson (1983) argues, standing "as a bridging substance between nature and culture, the human and the natural, the outside and the inside" (11), has made tampering with this link an irresistible theme in predictive discourses since the early articulations of scientific modernity. It is used either as an expression of faith in the potentially superior efficiency of technologically enhanced food production, or as a sign of skepticism or even fear of the dangers of a slide into the unknown territory of the "unnatural".

\section{Imagining the Futures of Food}

The first anticipatory impulse can be seen in late nineteenth-century and early twentieth-century predictions of the future of scientifically enhanced foodways. A good example of this optimistic vision can be seen in an article (and interview) published in the prestigious American McClure's Magazine in 1894 dedicated to perspectives of Professor Marcellin Berthelot ${ }^{8}$, described by the journalist Henry Dam as "one of the greatest living men of science" (303). In it, the Professor predicts that the food of the year 2000 would be mostly the result not of agricultural practices or cattle-rearing but of laboratorial work: "Wheat fields and cornfields are to disappear from the face of the earth," the reader is told, 
"because flour and meal will no longer be grown but made", while "beef, mutton and pork will be manufactured direct from their elements." Explaining that all edibles "consist almost entirely of carbon, hydrogen, oxygen and nitrogen", Professor Berthelot foresees that advances in synthetic chemistry will allow for the manufacture of "all food now grown by nature" (ibid), so that whatever natural fruits and vegetables might still be grown will be seen as decorative luxuries and not necessities. Although the Professor allows for the possibility that none of his predictions may happen and that "science may surely be permitted to dream sometimes" (312), a quasi utopian vision seems to illuminate his prognosis of a synthetic arcadia existing side by side with vast gardens freed from the burden of food production, "in which the human race will dwell amid a peace, a luxury and an abundance recalling the Golden Age of legendary lore" (ibid.).

Five years later, Arthur Bird's Looking Forward: A Dream of the United States of the Americas, 1999 (1899) explores an imagined world one hundred years in the future where imperialist dreams ${ }^{9}$ go hand in hand with the promises of technological prowess. Unlike Professor Berthelot, Bird does not seem particularly entranced with utopian possibilities of a happier, better life, but simply with a more efficient one. The production of food is framed by what David Belasco has called "technological agrarianism" $(2006,107)$. In 1999, Bird explains, describing that future as the present of a visitor/narrator, electricity is "on tap in every part of the farm", and "even the milking and stable cleaning is done by mechanical means". Free from the need to hire workers or to do much work themselves, "all agriculturalists" are "gentlemen farmers", served by electrical machines that, unlike human farmhands, never groan or complain and can "work all day without sitting under a shade tree" (181). This efficiency in farming is described as extending to food consumption as, in order to save time, people are said to often just have a pill for lunch, "a small pellet which contained highly nutritious food" (though quite how this is produced is never explained), having "little inclination to stretch their legs under a table for an hour at a time while masticating" (184).

Besides this overriding of social conventions, Bird also predicts that vegetarianism will gain more influence while still remaining a minority dietary preference ${ }^{10}$, and that new 
food sources will be available as people will drop their objections to eating horse meat (all those horses left without a purpose after the mechanization of agriculture) and raw fish. Occasionally the predictions turn into casual comedy - in the section about the press of the future, Bird imagines an advertisement for "Indestructible Food", "odorless rubber oysters cheap and durable, especially adapted to restaurants and church fairs" (180) -- but the text is strikingly free of any significant reflection on the possible downsides of these apparently rational manipulations of food production and consumption. Even in the 1930s, it is still possible to argue for the cogency of such impulses without much hesitation, as Winston Churchill does in his "Fifty Years Hence" essay (1932) where he predicts that "this power called science" would rationalize food production so that it would be possible to "escape the absurdity of growing a whole chicken in order to eat the breast or wing, by growing these parts separately under a suitable medium", a slide into the grotesque that is tentatively defused by his assertion that new foods such as these "will, from the outset, be practically indistinguishable from the natural products", and the changes "so gradual as to escape observation"(276).

This casual disregard for the ecosystem and the integrity of natural species clashes with the later cautionary warnings against scientific overreaching anticipated by H. G. Wells in The Food of the Gods (1904). This parable about the dangers of chemically manipulating animal food sources tells how Herakleophorbia IV, popularly known as Boomfood, a substance that accelerate the growth of animals (especially of chickens which increase their size six-fold), accidentally enters the food chain to eventually create gigantic humans known as Children of the Food. This early rejection of the transformative intrusion of technology in food production is invoked today, for example, in the use of familiar dystopian terminology in the campaigns of critics of biotechnology who describe Genetically Modified Foods as Frankenfoods, Farmageddon or Brave New Farm. Associated with Malthusian anxieties about overpopulation and exhaustion of resources, this denunciation of the dangerous manipulation of food has emerged in a number of what Domingo has called "Demodystopias"11 (2008) going back to the 1960s, a trend inaugurated by novels such as Harry Harrison's Make Room! Make Room! (1966). In this quasi- 
apocalyptic novel, the political protocols of access to natural versus artificially concocted foodstuffs are used as a signifier of economic hierarchies and other social divisions in an overpopulated world, where most of the 35 million inhabitants of New York are desperately poor and survive on Soylent Green. They think this is a compound of soybeans and lentils but it is in fact a concoction of recycled motor oil, plankton, white blubber and algae, and in the famous film adaptation Soylent Green (1973) it becomes a substance composed of recycled dead humans.

This contemporary technophobic imagination ${ }^{12}$, born out of the experience of late modernity, contrasts with the vast body of technological utopias shaped by the belief that the progress of science and its practical applications will harbinger not just greater efficiency, but greater happiness. In the American utopian tradition, the fifty years bracketed between the publication of John MacNie's The Diothas: or, A Far Look Ahead in 1883 and Harold Loeb's 1933 Life in a Technocracy: What it Might be Like offer a particularly fertile field of observation of this type of investment in mythologies of everincreasing man-made progress, guided by the premise that human mastery over an adversarial sphere of the natural, led by reason and governed by ethics, would be instrumental to the improvement of mankind's condition. Howard Segal, who has identified and discussed many of these American texts, suggests that this proclivity may be explained by the intellectual dominance of the rhetoric of the "technological sublime" discussed by Perry Miller, Leo Marx and David Nye ${ }^{13}$, which has always stood at the center of the national narrative to the degree that reliance on applied scientific advancement oftentimes supplants, as Segal observes, proposals of social rearrangements, especially in this period (2005:2). Many of these articulations of techno-utopianism do in fact equate progress with practical achievements brought about by advancing efficiency in production and in communication and transportation systems thought to establish new conditions that would improve humanity's choices in terms of work and lifestyle, freeing citizens not only from poverty, hard and repetitive labor, but also from major sources of individual and collective unhappiness, ranging from illness, crime, social disorder and urban dysfunction to war, thus enabling them to attain emotional and psychological harmony. 
In contrast, utopias that echoed the attachment to simple living, village-based communal values, subsistence farming and handcrafts were not common in America in this period. One possible exception might be William Dean Howell's A Traveler from Altruria (1894) where the imagined island of Altruria ${ }^{14}$, standing as a foil to the late nineteenthcentury urban life of Gilded Age America, is described by one of its inhabitants visiting America as a "pastoral utopia of radical simplicity where wood-chopping, mushroomgrazing villagers resist specialization and many modern comforts", but are nonetheless served by a good system of roads and electricity (Belasco, 2006: 103).

Significantly, most of these American nineteenth- and early twentieth-century texts present themselves not as distant visions of dreamy better futures that may happen in some unpredicted time and place, but as grounded and attainable rationally driven tomorrows that are not "unscientific, out of touch with reality" utopias "in the clouds", as Charles Williams Wooldridge would explain in the preface to his 1902 Perfecting the World: A Piece of Possible History, but extrapolations which remain "true to the laws of cause and effect, and duly regarding the limitations of nature" (11).

\section{Techno-utopian Meals}

The two texts selected for closer discussion stand at almost opposite ends of this probability axis in the way they imagine the production and consumption of food Roadtown, a tract by Edgar Chambless ${ }^{15}$ (1910), which attempted to defend its radical reconfiguration of the relationship between nature and technology, city and countryside as rationally attainable, and Mizora, a speculative utopian novel by Mary Bradley Lane (1898), which would appear to critics like Wooldridge as the perfect example of a "utopia in the clouds", structured as it is upon premises of impossibility.

Roadtown presents itself as a rational response to the plight of overcrowded cities "offering a single unified plan for the arrangement of these three functions of civilization production, transportation, and consumption" (30). This would be achieved by upturning the relationship between urban and rural, reinventing both the city and the system of 
transportation. As Chambless explains: "the idea occurred to me, to lay the modern skyscraper on its side and run the elevators and the pipes and wires horizontally instead of vertically". Not limited by "the stresses and strains of steel", this new kind of house "could be built with not only a hundred stories, but a thousand stories or a thousand miles" along railway tracks, taking "the apartment house and all its conveniences and comforts out among the farms by the aid of wires, pipes and of rapid and noiseless transportation." This city/road combination would, Chambless adds, "surround the city worker with trees and grass and woods and meadows and the farmer with all the advantages of city life" (19-20). Bordered by farmland, the new linear city would contain not only apartments and other urban necessities but facilities that would make life not only practical but pleasant. In the basement a system for transporting passengers, freight, parcels and all utilities would be set up, and, on the roof, a street would become an upper promenade for walks, cycling and summer entertainment (53).

Agricultural life would also be drastically changed by the fact that distances between production and consumers, characteristic of conventional cities, would be drastically cut, as well the distance between the farmer and what Chambless calls "the luxuries and refreshments of civilization" like schools or the post office, all accessible now in the nearby perpendicular town. As for the quality of the food produced, this proximity would make it cheaper and fresher, "bought in bulk from the makers at makers' rates" (87), eliminating the middlemen and the profits of retailers and distributors as well as "the cost of bottles and cans, of delivery boys and bad grocery bills" (87-88). Purchased from the nearby farms and immediately consumed, "vegetables will be crisp and fresh" (87), now that the distance between producer and market would be at most "half a mile", "one tenth of the distance under present conditions" (91).

This fresh food would, in the cooperative and efficient spirit of the linear city, be prepared and eaten in different modes from what Chambless describes as dominant modes - "the dining-out habit and the delicatessen habit" (81). The problem with the first is that it is expensive in terms of time and money (therefore inefficient) and "destroys the most delightful hours of home life" (and is, therefore, psychologically damaging). The second 
offers a bad diet, consisting, so we are told, chiefly of "bread, cold meat and pickles" (ibid.) Both are particularly ineffective in terms of transportation - in the first case, people have to be taken to the food and in the second food must be taken into the home, "limiting the quality, quantity and variety of the available meal" (ibid). In the new utopian straight-line Roadtown, these difficulties would be solved by technology, namely the use of mechanical carriers which would make delivery inexpensive, noiseless and efficient. This food would be communally prepared in a number of large bakeries, creameries, and boiling and roasting establishments, and sent in suitable quantities to serving stations within half a mile of where the cooking will happen. Sitting in the privacy of their dwellings, Roadtowners "will order by phone" and "the foods will be on the dining-room sideboards in less time than it takes to bring it by the two-legged route from Delmonico's kitchen to his dining-room", ready to be opened and arranged upon the table by the womenfolk, so that, the reader is told, there is still "a homely virtue left" (82). Complex details are added about the disposal procedures, but we are generally told that dishes, food remnants and soiled linen will be swiftly dropped down a chute (we had already been told about the use of new resilient materials for dishes and glasses) and taken to a public dish-washery where a few men, who are not to be thought of as servants, which, the text promises, will no longer be needed (89), will with the aid of machinery "do the work which now occupies half a hundred mothers." These will now be able to join their families in the "library, the music room or indulge in a nap"(83).

This disciplining of the messiness and disorder of the urban into an efficient, precise, cooperative and harmonious urban/rural system, and the reconfiguring of the links between the farm and the city, touches on food production and consumption, but not on the essence of either agricultural practices or the naturalness of food.

This is not where Mary Bradley Lane takes us in Mizora (1890)16, which departs from the technological agrarianism embraced by Arthur Bird in his description of "gentlemen farmers" helped by electrical machines and appears to have more in common with the possibilities addressed by Professor Berthelot. In this novel, a female observer, Vera, a Russian political fugitive, ${ }^{17}$ finds her way into the secret inner-earth world of 
Mizora, a single-sex self-sufficient utopia which precedes Charlotte Perkins Gilman's better known Herland by three decades. Mizora, as she describes it, is a society of "practical chemists" (19) where applied science is central to a project of empowerment dependent, as Christine Mahady points out, on "the utopian potential in reconceptualizing human relationships with nature" (Mahady, 2004:94). Claiming to be "a people who have passed beyond the boundary of what was once called Natural Law" to have become "mistresses of Nature's peculiar processes" (90), the Mizorans have developed the capacity to manipulate the environment in many forms. Besides the procedures of parthenogenesis that enable them to procreate without men, they use electricity to produce rain and a system of "artificial heat" based on the "decomposition of water" from which an economical fuel is produced (59). Their retreat from the natural in the production of chemically synthesized food, of particular importance for the present discussion, is not caused by scarcity, overpopulation or any other of the themes that emerge in contemporary dystopias like Harrison's Soylent nightmare, but is instead a deliberate decision intended to promote health, separating humans from the "deleterious earthy matter" (45) associated with the soil. Vera is told that the Mizorans have long rejected agriculture, an art that had "vanished in the dim past of their barbarism" (27), and do not keep cattle, but that, as highly skilled practical chemists, they have found synthetic substitutes for the foodstuffs these activities would provide.

It is true that, in line with Belasco's observations about the feminine sphere of control of the fruit and vegetable garden ${ }^{18}$ (107), they keep orchards and gardens and eat gorgeously tasty fruits and vegetables, but we soon learn that these have been manipulated to look more attractive. Vera tastes some cherries which are seedless and have the color and transparency of honey, and is told that the Mizorans are able to keep their fruit and vegetables in their natural state for years without them decaying or losing their flavor (53). But even these chemical preservation methods do not satisfy the Mizorans and, unhappy with any connection with the "earthy matter lingering on all food derived from the soil", their laboratories are already investigating the production of artificial fruit and vegetables 
that "will satisfy the palate and be free from the deleterious matter" they find so unhealthy and repugnant (47).

As they have no cattle, all milk, butter, cheese and cream are synthetically assembled by elements, and so is meat, as Vera finds out when she partakes of "something that resembled beefsteak of a very fine quality" and later learns had been "chemically prepared meat" (18). The main components of their bread have a particularly disturbing origin stone, in particular "the limestone and the refuse of the marble quarries" left over from the building of their elegant mansions, a cheap product with an inexhaustible supply as "there are always mountains where the stone is abundant" (36).

These cheap, plentiful and tasty artificial foods were sold, as Vera finds out, in colorful markets which reinvent the concept of selling by actually having no salespeople. Next to the "baskets of fruits, bunches of vegetables", all with a price label, are other wicker baskets to receive the change. With no scarcity and no social hierarchies, the Mizorans apparently also have no crime.

The protocols of cooking, a highly valued science, are also detailed by the fascinated Vera. The first significant observation is Lane's distancing from projects of collective cooking so characteristic of the progressive utopias of her time in favor of a kind of culinary individualism, which is explained to Vera in terms of efficiency; they had tried to establish cooking as a public business, as they did with other household chores, but had "always found it impractical". This was because if what was palatable to one person would be disliked by another, then preparing food for a large number of customers without knowing exactly what the demand was would inevitably lead to waste (47). So they had adopted the practice of training highly skilled cooks, required to be "chemists of the highest excellence" (45), who are treated with as much honor as Vera's country awarded sculptors, painters and writers (43). The kitchens where they work, kept clean by machines "with brushes and sponges attached" (44) and other implements which do all the hard work, are in fact akin to laboratories. All seasoning is done precisely by weight and measure, avoiding impulsive and unscientific human actions like stirring or tasting, and a "glass tube, on the principle of a thermometer, determined when each article was done" (45) thereby avoiding all danger of 
subjectivity, a mechanical procedure that might disqualify them from being described as creative artists.

There is a subtle and perhaps disturbing quality in this obsession with the clean and unpolluted if linked with the Mizorans concern with health and purity. They are all in fact not only elegant and knowledgeable, but remarkably vigorous and beautiful, a quality they attribute to the healthy, unsoiled food they eat and to which they also attribute the delay in ageing processes. They are also all decisively white and blonde, studiously preserving their racial makeup, as Broad notes, "through a pseudoscientific combination of biological evolution and eugenics" that maintains and purifies whiteness "through the regulation of female sexuality and reproduction" (247), ensuring that undesirables of any kind could not procreate. Seen though this wider framework, the rejection of the earthy wheat and the liking for bread made from stones acquires, arguably, a much less utopian taste.

How far speculative fiction will be able to move away from the natural/artificial dichotomies that have shaped the literary representations of food is an open question. In many contemporary post-singularity, post-human technological utopias, set in post-scarcity societies of the future, where work and even death have been rendered optional, food is not bought or prepared, though it is certainly eaten. As Eric Drexler points out in Engines of Creation (1986), his influential book on the coming era of nanotechnology, in the not so distant future molecular replicators and assemblers will be able to supply most of our needs; in the meantime, as he expands in a more recent text, Atomically Precise Manufacturing has the capacity to meet the growing demands for food while respecting environmental constraints by facilitating enclosed agriculture, (231-232) including the pioneering efforts in the area of vertical agriculture ${ }^{19}$. As we witness the growing capacity of 3D printers to actually print prepared food, we may be reminded of theoretical physicist Michio Kaku's statement (2012), separated by more than 120 years from the predictions of Professor Berthelot, that since all food is made of the same elements as, say, a glass, a molecular assembler will be able to break up any substance at its atomic level and join the components in different combinations to create new substances. In the futuristic utopias of infinite abundance, from Charles Stross to Cory Doctorow, ubiquitous assemblers provide 
all you need, from food to shoes, using the same disassembling and reassembling methodology 20 .

If this is ever to be the case, then the textured cultural reading of food may no longer operate and we may come to partially agree with the Mizorans, rationalizing that if all foodstuffs are made of the same chemical elements, it does not really matter where they come from. But until that happens, it is almost impossible to imagine a more powerful signifier of the fragility of the human body, of the power relations that allow it to flourish or to perish, and of the many possible worlds it allows our imagination to inhabit.

\section{NOTES}

${ }^{1}$ Lawrence Sanders (1920-1998 is best known as a prolific writers of popular thrillers. The Tomorrow File was his only incursion into the field of speculative, dystopian fiction.

${ }^{2}$ The megapolis that extends from Boston to the North of Washington (27-28)

${ }^{3}$ In the novel a biologically based hierarchy separates "natural born" from artificially- or inseminated-born, complemented by genetically based scales that purportedly relate to capacity and intelligence.

${ }^{4}$ The social order described in the novel had been initiated in the 1990s by President More, a microbiologist, and is maintained by chemically induced efficiency and stupor. Civil servants like Nick and Paul, with high genetic grades, regularly take Supermem, a drug that augments their memory to such an extension that they rarely forget the most trivial of information, and most frequent flyers use Somnorific, a perfectly tuned sleeping pill that comes in one to three hour doses. Opponents of this "happiness through chemistry order", like Paul's mother, exit in the margins, dismissed by the political rulers and popular discourse as Obsos (Obsoletes). 
${ }^{5}$ In the fictional world of the Bas-Lag trilogy the term Xenian is used to refer to a number of hybrid and nonhuman species that live side by side with humans.

${ }^{6}$ The Khepri are a species of humanoid scarab beetles; their females have bodies that are indistinguishable from those of human women, but they have large beetle-like heads, and no vocal cords. They communicate with humans by means of sign language,

${ }^{7}$ Bacigalupi has used this descriptor to characterize the novella, since the main character is a kind of hacker who seeks to break a corporate stronghold on a biological level by attempting to sow and cultivate unpatented seeds (cited in Kelly and Kessel 2007:337)

8 Pierre Marcellin Berthelot (1827-1907) was a French chemist knows for his work in synthesizing many organic compounds from inorganic substances. He is considered one of the greatest chemists of all time.

${ }^{9}$ Bird predicts, for example, the unification of the Americas under the hegemony of an enlarged United States as one by one, beginning with Peru, Central and Southern American nations voluntarily ask to be admitted as states of the Union. He also predicts the complete obliteration of Spain, the United States' enemy during the Spanish-American war of 1898, from the map of Europe.

${ }^{10}$ His treatment of the issue of vegetarianism is shaded by quasi-satirical undertones, suggesting, for example, that the vegetarians of the future will "refuse to wear leather shoes as a gesture of philosophical coherence".

${ }^{11}$ Domingo defines this subgenre as fiction concerned with the negative effects of the evolution of population and changing demographics. Citing the writer Lionel Shriver (2003), Domingo identifies three subject categories in these texts: fear of population decline, fear of population excess, and fear of population professionals who direct the course of demographic change.

12 This is by no means the only contemporary influential vision of the promises of science and technology as the corpus of post-singularity, post-human literature, including the ironic critical utopias of Charles Stross or Cory Doctorow, attests.

${ }^{13}$ See, Perry Miller (1965) The Life of the Mind in America: From the Revolution to the Civil War. New York: Harvest Books; Leo Marx (1964) The Machine in the Garden: Technology and the Pastoral Ideal in America. New York: Oxford University Press; David Nye (1996) American Technological Sublime. Cambridge: MIT Press

${ }^{14}$ Altruria, from the Latin alter "the other", invokes the utopian ethics of the Island based on the concept of altruism, and not self-interest.

15 This concept of a house-wide linear city engaged the support of Thomas A. Edison, and will emerge later in Robert A. Heinlein's short story "The Roads Must Roll" (1940). 
16 Before appearing in book format in 1890, Mizora had been published in serialized form in the Cincinnati Commercial newspaper between 1880 and 1881.

17 Vera is a Russian victim of Czarist repression who escapes from Siberia only to find herself in the Arctic, where her boat falls through a waterfall to the land of Mizora.

${ }^{18}$ As opposed to the masculine domains of intensive farming and cattle breeding (Belasco, 16-17)

${ }^{19}$ Vertical agriculture can be described as the practice of producing food indoors, in vertically stacked layers, such as in a skyscraper, used warehouse, or shipping container, using controlled-environment agriculture technology, where all environmental factors can be controlled. (The Vertical Farm: Feeding the World in the Twenty First Century http://www.verticalfarm.com/ viewed 10 March 2017)

${ }^{20}$ See Cory Doctorow Down and out in the Magic Kingdom, New York: Thor Books (2003), Charles Stross, Glasshouse, London: Orbit (2006), and Accelerando, London: Orbit (2005). 


\section{Works cited}

Atkinson, Paul (1983), "Eating Virtue", in The Sociology of Food and Eating: Essays on the Sociology and Significance of Food. Ed. Anne Murcott. Aldershot, Gower: 9-17.

Atwood, Margaret (1999), The Handmaid's Tale. London: Vintage [1985].

Bacigalupi, Paolo (2008), "The Calorie Man", in Pump Six and other Stories. San Francisco, Night Shade Books: 93-121.

Belasco, Warren (2006), Meals to Come: A History of the Future of Food. Berkeley, University Press of California.

Bird, Arthur (1800), Looking Forward: A Dream of the United States of the Americas, 1999. Uthica, Press of L.C. Child's and Son.

Broad, Katherine (2009), "Race, Reproduction, and the Failures of Feminism in Mary Bradley Lane's Mizora" Tulsa Studies in Women's Literature, Vol. 28, No. 2: 247-266.

Lane, Mary E. Bradley (1889), Mizora: A Prophecy. A Mss. Found Among the Private Papers of the Princess Vera Zarovitch, Written by Herself. New York, G.W. Dillingham Publisher.

Chambless, Edgar (1910), Roadtown. Melbourne: Leopold Classica Library [reprint].

Churchill, Winston (1932), "Fifty Years Hence”, in Thoughts and Adventures. London, T. Butterworth: 269-280.

Dam, Henry J. W. (1894), "Food in the Year 2000: Professor Berthelot's Theory that Chemistry Will Displace Agriculture." McClure's Magazine, September: 303-312.

Domingo, Andreu (2008), “'Demodystopias': Prospects of Demographic Hell.” Population and Development Review Vol. 34, No 4: 725-745.

Drexler, Eric K. (1986), Engines of Creation: The Coming Era of Nanotechnology. New York, Anchor Books.

-- (2013), Radical Abundance: How a Revolution in Nanotechnology Will Change Civilization. 
New York, Public Affairs.

Forster, Laurel (2004), “Futuristic Foodways: The Metaphorical Meaning of Food in Science Fiction Film", in Reel Food: Essays on Food and Film. Ed. Anne L. Bower. New York, Routledge: 251-265.

Harrison, Harry (2008), Make Room! Make Room!, London, Penguin.

Howells, William Dean (1908), A Traveler From Altruria. New York, Harper \& Brothers Publishers.

Loeb, Harold (1959), Life in a Technocracy: What it Might be Like. New York, Criterion [1933].

Kaku, Mishio (2012), “Can Nanotechnology Create Utopia?” Big Think Podcast, https://www.youtube.com/watch?v=RzgVWpa4fzU (viewed 2 March 2016).

Kelly, James Patrick and John Kessel (2007), Rewired: The Post-Cyberpunk Anthology. San Francisco, Tachyon Publications.

Mahady, Christine (2004), “No World of Difference: Examining the Significance of Women's Relationship to Nature in Mary Bradley Lane's Mizora". Utopian Studies Vol. 15, No 2: 93115.

Miéville, China (2000), Perdido Street Station. London, Pan Books.

Orwell, George (1978), Nineteen Eighty-Four. Harmondsworth, Penguin [1949].

MacNie, John (pseudo. Ismar Thiusen) (1971), The Diothas: or, A Far Look Ahead. New York, Arno Press [1883].

Parasecoli, Fabio (2008), Bite Me: Food in Popular Culture. Oxford, Berg.

Parker, Emma (1995), "You are What you Eat: The Politics of Eating in the Novels of Margaret Atwood." Twentieth Century Literature, Vol. 41, No 3: 349-368.

Sanders, Lawrence (1975), The Tomorrow File. London, Corgi Books.

Segal, Howard (2005), Technological Utopianism in American Culture. Syracuse, Syracuse

N. 36 - 06/ 2017 | 23-42 - ISSN 2183-2242 | http:/dx.doi.org/10.21747/21832242/litcomp36a1 41 


\section{University Press.}

Shriver, Lionel (2003), "Population in Literature." Population and Development Review 29, No2: 153-162.

Retzinger, Jean P. (2008), "Speculative Visions and Imaginary Meals: Food and the Environment in (Post-Apocalyptic) Science Fiction Films." Cultural Studies, Vol. 22, Nos. 3-4: 369-390.

Wells, H.G. (2010), The Food of the Gods. London, Orion Publishing Group [1904].

Wooldridge, William Charles (1971), Perfecting the Earth: A Piece of Possible History. New York, Arno Press [1902].

Maria Teresa Botelho has a PH.D. from Cambridge University and is Associate Professor at The Faculty of Social and Human Sciences, Nova University of Lisbon, where she teaches American Studies. She is President of the Portuguese Association of Anglo-American Studies and member of the research group: Mapping Dreams: British and American Utopianism (CETAPS). She has published extensively on African American, and Asian American culture and literature, theater and drama. Her current interests include technological utopias/dystopias and the post-human, science fiction, post-black literature, identity theory in its intersections with utopia, visual culture and cinema, the collaboration between sciences and literature, especially in drama, and literary and visual representations of 9/11. 